\title{
Absence of direct effects of GnRH on testicular steroid secretion in the ram
}

\author{
J. C. Meijer, V. L. Trudeau†, F. H. de Jong $\ddagger$, M. Bevers*, \\ E. N. Noordhuizen-Stassen* and C. J. G. Wensing
}

Department of Functional Morphology and *Department of Herd Health and Reproduction, Faculty of Veterinary Medicine, University of Utrecht, The Netherlands; and $\ddagger$ Department of Biochemistry, Medical Faculty, Erasmus University Rotterdam, The Netherlands

\begin{abstract}
Summary. Effects of GnRH, administered via the testicular artery, on testicular steroidogenesis were studied in rams during the non-breeding season. Concentrations of testosterone and 17-hydroxyprogesterone in testicular venous blood showed similar profiles which were identical for GnRH-treated ( $0.5 \mathrm{ng}$ infused over $60 \mathrm{~min}$ or $25 \mathrm{ng}$ injected) and control testes. Increases of testicular venous concentration of both hormones were only marginally reflected in peripheral venous concentrations. Peripheral administration of hCG (200i.u., i.v.) stimulated testosterone secretion to a larger extent than 17-hydroxyprogesterone secretion in 10/11 rams, GnRH-treated and control testes showing identical responses. High testicular venous concentrations of both hormones after administration of $\mathrm{GnRH}$ were paralleled by increased concentrations of endogenous LH. These LH peaks were evoked by $25 \mathrm{ng} \mathrm{GnRH}$ in $7 / 8 \mathrm{rams}$. The observed effects of GnRH treatment on testicular steroid secretion thus cannot be considered to be the result of direct stimulation of steroidogenesis by GnRH.
\end{abstract}

Keywords: GnRH; in vivo; testis; ram; testosterone; progesterone

\section{Introduction}

The effects of GnRH and its agonists on testicular steroidogenesis may involve both pituitary and testicular levels of action. Direct action of GnRH on rat Leydig cell function has been documented to occur both in vitro (Hsueh \& Erickson, 1979; Sharpe, 1982) and in vivo (Sharpe et al., 1983; Kerr \& Sharpe, 1986). In rats chronic administration of GnRH and its agonists inhibits testicular steroidogenesis via reduction of testicular $\mathrm{LH}$ receptors and decreased activity of the 17-hydroxylase-17,20-desmolase enzyme complex (Dufau et al., 1979; Kerr \& Sharpe, 1986). Acute administration of GnRH, however, initially stimulates steroidogenesis in vivo (Sharpe et al., 1983) and in vitro, probably by activation of cytochrome P450 enzyme activity (Sullivan \& Cooke, 1983).

Direct effects of GnRH on gonadal steroid secretion, which have also been reported for nonrodent species (Sharpe, 1982), are believed to reflect the physiological action of gonadal GnRH-like peptide (Sharpe, 1984). However, the presence of both specific GnRH binding and GnRH-like peptide has been documented only for the rat testis, although GnRH-like peptide has been isolated from gonads of species apparently lacking gonadal GnRH receptors (Aten et al., 1987; Brown \& Reeves, 1983). The physiological significance of GnRH-like peptide and of the direct gonadal actions of $\mathrm{GnRH}$ and its agonists is as yet unresolved.

The purpose of the present experiment was to investigate whether acute GnRH treatment directly affects testicular steroid secretion in a non-rodent species under physiological conditions.

†Present address: Department of Zoology, University of Alberta, Edmonton, Canada T6G 1E1. 
We have chosen to explore the intact ram because of the accessibility and diameter of its testicular blood vessels, allowing blood sampling of each testis separately, and the availability of data on LH-releasing properties of low doses of GnRH.

\section{Materials and Methods}

Animals and surgery. Texel rams, 1-year-old and $\sim 50 \mathrm{~kg}$ body weight, were investigated during the non-breeding season in March-April. The 11 rams were surgically implanted with a Teflon cannula (Abbocath-T 20G, Abbott Ireland Ltd, Sligo, Ireland) in the distal testicular artery and the distal testicular vein of the left and right testis (Noordhuizen-Stassen, 1984) and in the cephalic vein. During the experiments the rams were kept under halothane/ nitrous oxide anaesthesia.

Blood was collected from the 3 cannulated veins at $-60,-30,0,10,20,40,60,90,120,150,180,200,220$, and $240 \mathrm{~min}$ and stored on ice in heparinized tubes. Plasma was separated within $1 \mathrm{~h}$ and stored frozen at $-70^{\circ} \mathrm{C}$ until assayed.

Experiment 1 . At time 0 in $8 \mathrm{rams}$, the left testicular artery was slowly (over $1 \mathrm{~min}$ ) injected with $1 \mathrm{ml}$ vehicle $(0.1 \%$ gelatin in saline) and the right testicular artery was injected with $25 \mathrm{ng} \mathrm{GnRH}$ (Fertagyl: Intervet, Boxmeer, The Netherlands) in $1 \mathrm{ml}$ vehicle. At $180 \mathrm{~min}, 200 \mathrm{i} . \mathrm{u}$. hCG (Chorulon: Intervet) were injected into the cephalic vein.

Experiment 2. The left and right testicular arteries of 3 rams were infused for $1 \mathrm{~h}$, starting at time 0 . The left testis received vehicle only and the right testis $0.5 \mathrm{ng} \mathrm{GnRH}$ in a volume of $5 \mathrm{ml}$ vehicle. At $180 \mathrm{~min}, 200 \mathrm{i} . \mathrm{u}$. hCG were injected into the cephalic vein.

Hormone assays. Testosterone and 17-hydroxyprogesterone were estimated by previously validated radioimmunoassays (Verjans et al., 1973; de Jong et al., 1984). The intra- and interassay coefficients of variation were $<9$ and $<12 \%$ respectively for both assays. Sensitivity was $50 \mathrm{fmol}$ testosterone/tube and $125 \mathrm{fmol} 17$-hydroxyprogesterone/ tube.

Concentrations of luteinizing hormone (LH) were estimated with a double-antibody radioimmunoassay for bovine LH (Dieleman et al., 1983) using ovine LH (NIH-LH-S17) as a standard. Sensitivity of the assay was $10 \mu \mathrm{g} / 1$ and the intra-assay coefficient of variation was $2.5 \%$; all $\mathrm{LH}$ determinations were done in one assay. Cross-reaction of hCG with the LH antiserum was found to be less than 1\% (pure hCG, 10900 i.u./mg, gift of Biosynth B.V., Oss, The Netherlands).

Testosterone and 17-hydroxyprogesterone were estimated in the testicular and peripheral plasma. LH was estimated in peripheral plasma only.

Analysis of the data. Effect of treatment (i.e. GnRH and hCG administration) was analysed by comparing pre- and post-treatment values for testosterone, 17-hydroxyprogesterone and LH. Since the data were normally distributed, Student's paired $t$ test was used. Differences in steroid secretion between control and treated testes were analysed with Student's paired $t$ test.

\section{Results}

\section{Experiment 1}

Testosterone. Concentrations of testosterone in venous blood from GnRH-treated testes and control testes were not significantly different (Fig. 1). The overall mean ratio for plasma testosterone concentrations of treated versus control testes was $1.05 \pm 0.03$ (mean \pm s.e.) for 105 paired samples. Concentrations of testosterone in the venous outflow of both testes increased $(P<0.01)$ after GnRH treatment of one testis. Individual responses, however, varied (Fig. 1) with 5/8 rams showing obvious increases of testosterone concentrations in testicular blood, 2/8 rams showing no or slight increase and one ram (No. 7) starting with high testosterone concentrations that decreased during the $3 \mathrm{~h}$ period after GnRH injection.

All rams responded to the administration of hCG with increases of testosterone in testicular venous blood $(P<0.01)$; only the control testis of Ram 8 did not respond to hCG treatment.

Peripheral venous concentrations of testosterone (Fig. 2) were orders of magnitude lower than testicular venous concentrations and reflected changes in the latter concentrations to only a minor extent. Mean basal (pre-GnRH) concentrations of testosterone in peripheral and testicular plasma for $7 / 8$ rams were $1.16 \pm 0.19$ (mean \pm s.e.) and $40.0 \pm 7.38 \mathrm{nmol} / 1$ respectively (Ram 7 was 


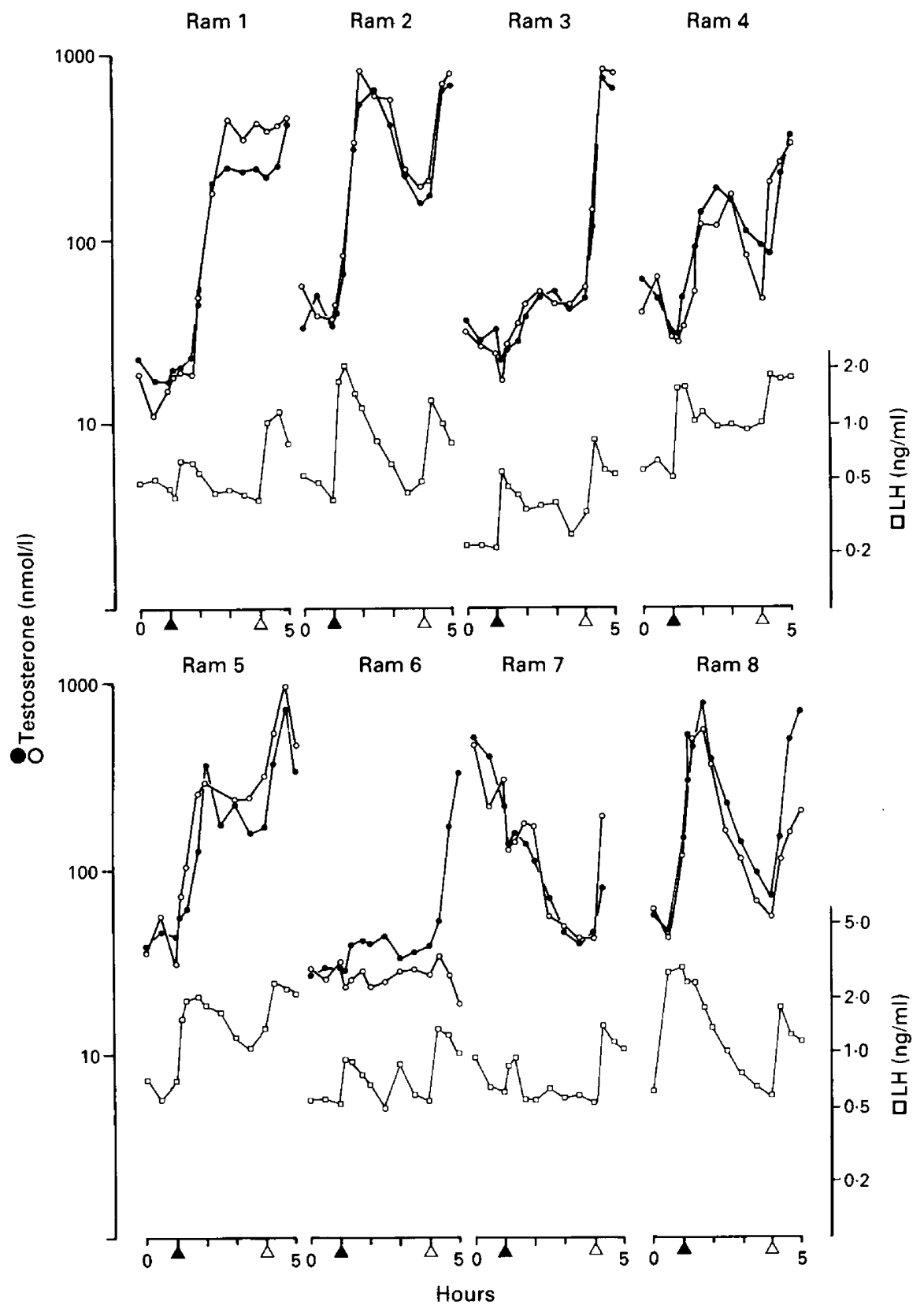

Fig. 1. Profiles of testosterone in testicular venous plasma from saline-treated $(\mathrm{O}-\mathrm{O})$ and GnRH-treated (-O) testes in individual rams (Nos 1-8). LH concentrations in peripheral plasma ( $\square-\square)$ are shown in the lower part of each graph. $\Delta$, Injection of $25 \mathrm{ng} \mathrm{GnRH}$ at $1 \mathrm{~h} ; \triangle$, injection of $200 \mathrm{i} . \mathrm{u}$. hCG at $4 \mathrm{~h}$.

excluded because of very high basal concentrations). Peripheral concentrations of testosterone after administration of GnRH and hCG were not significantly different from pretreatment concentrations.

17-Hydroxyprogesterone. Concentrations were slightly higher $(P<0.05)$ in venous blood from GnRH-treated testes compared with control testes. The ratio for plasma concentrations from 

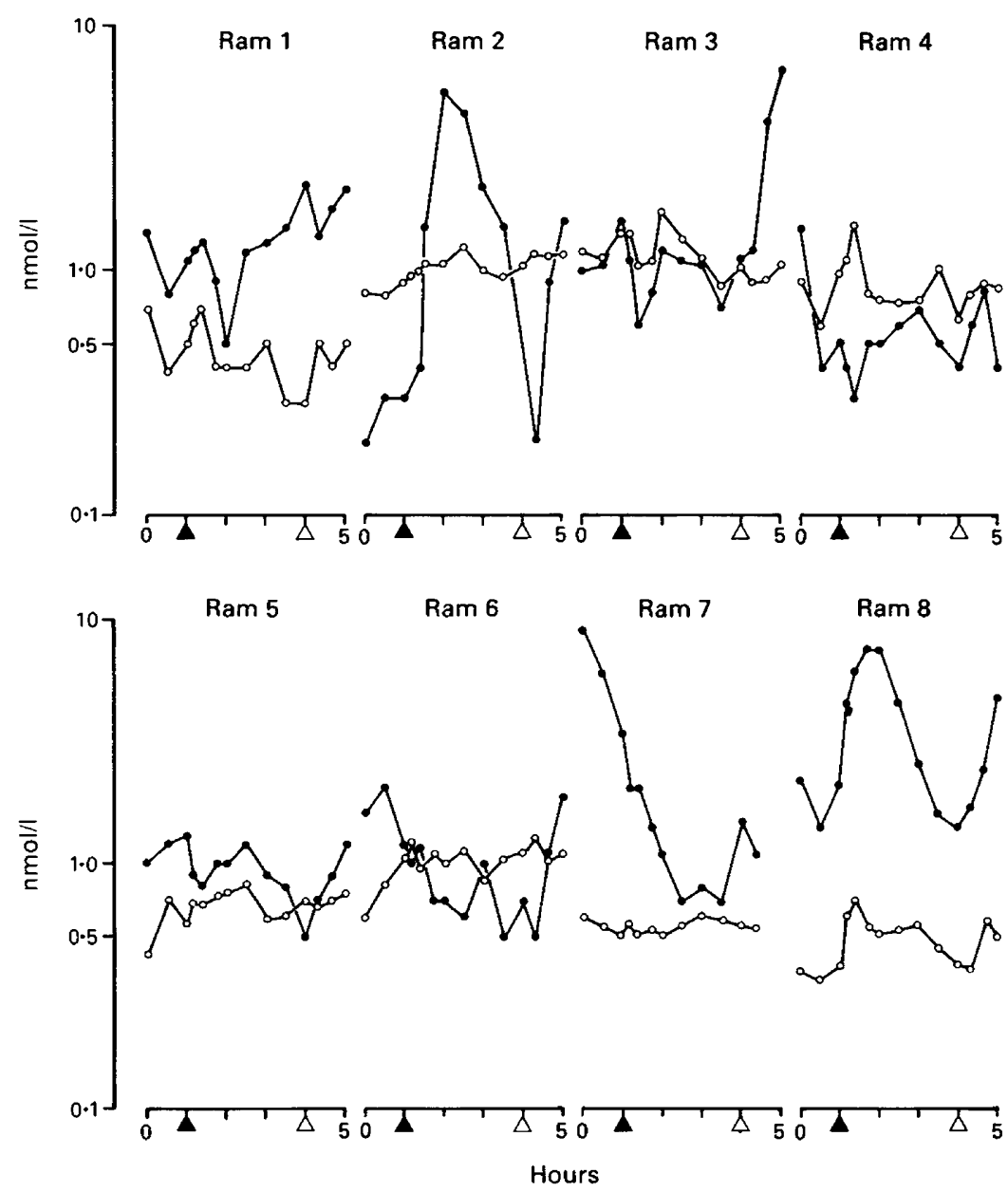

Fig. 2. Profiles of testosterone (- $)$ and 17-hydroxyprogesterone $(\mathrm{O}-\mathrm{O})$ in peripheral plasma of individual rams (Nos 1-8). $\Delta$, Injection of $25 \mathrm{ng} \mathrm{GnRH}$ at $1 \mathrm{~h}$ into one testicular artery; $\triangle$, injection of $200 \mathrm{i}$.u. hCG at $4 \mathrm{~h}$ into the cephalic vein. Note the different scales used in Figs 1 and 2.

treated versus control testes, however, was not affected significantly by this slight difference and was $1.08 \pm 0.02$ (mean \pm s.e.) for 104 paired samples. Concentrations of 17-hydroxyprogesterone increased $(P<0.01)$ in the venous outflow of both testes after GnRH treatment of one testis and after administration of hCG (Fig. 3). Peripheral venous concentrations (Fig. 2) were lower than, but in the same range as, testicular venous concentrations. Mean basal concentrations of 17 hydroxyprogesterone in peripheral and testicular venous plasma were $0.74 \pm 0.11$ (mean \pm s.e., $n=8$ ) and $0.90 \pm 0.08 \mathrm{nmol} / 1$ respectively. Increases after GnRH or hCG were less prominent in peripheral blood than in testicular blood. These peripheral increases were of statistical significance $(P<0.02)$ in the 1 -h period after $\mathrm{GnRH}$ administration but not after hCG.

$L H$. In $7 / 8$ rams the $\mathbf{L H}$ concentrations in peripheral plasma increased following the administration of $25 \mathrm{ng} \mathrm{GnRH}(P<0.02)$, the mean increment being $0.73 \pm 0.22 \mathrm{ng} / \mathrm{ml}$. In the remaining ram, the high basal value decreased slightly (Fig. 1). After the injection of $200 \mathrm{i} . \mathrm{u}$. hCG, the concentrations of $\mathrm{LH}$ increased $(P<0.01)$ in all rams. 

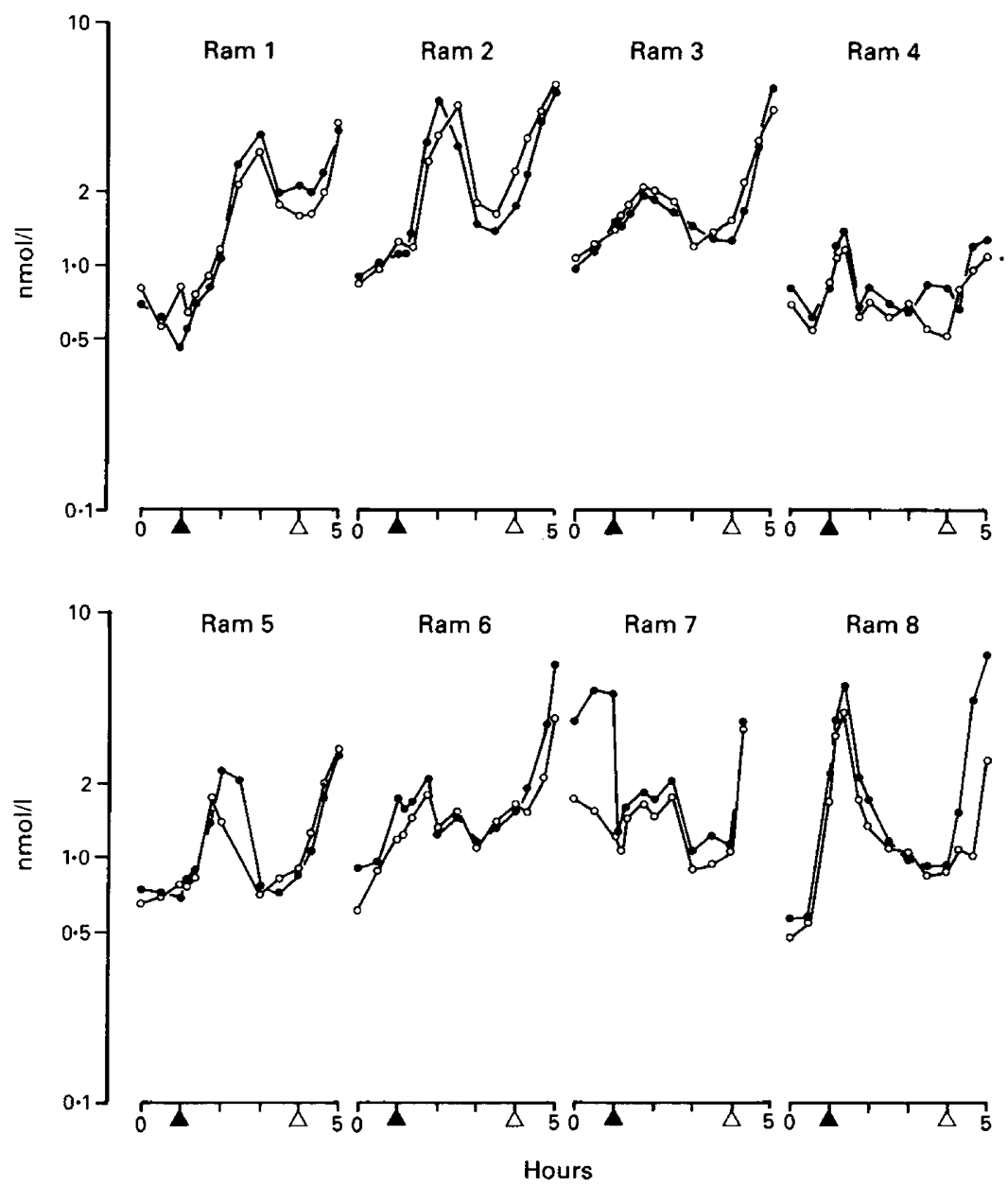

Fig. 3. Profiles of 17-hydroxyprogesterone (nmol/l) in testicular venous plasma from salinetreated $(\mathrm{O}-\mathrm{O})$ and $\mathrm{GnRH}$-treated testes (-O) in individual rams (Nos 1-8). Injection of $25 \mathrm{ng} \mathrm{GnRH}$ at $1 \mathrm{~h} ; \triangle$; injection of $200 \mathrm{i} . \mathrm{u}$. hCG at $4 \mathrm{~h}$.

\section{Experiment 2}

In this experiment $(0.5 \mathrm{ng}$ GnRH infused over $1 \mathrm{~h})$ testosterone and 17-hydroxyprogesterone were determined in testicular venous blood only. Concentrations did not differ between control and treated testes. Only Ram 3 showed significant increases of both hormones after GnRH treatment. This increase was paralleled by increasing concentrations of $\mathrm{LH}$ in peripheral plasma (Fig. 4).

All 3 rams responded to hCG treatment with increased secretion of testosterone and 17-hydroxyprogesterone and increased peripheral concentrations of $\mathrm{LH}$.

\section{Discussion}

The results of the present experiments show that testosterone and 17-hydroxyprogesterone concentrations in testicular venous blood are much more sensitive indicators of increased testicular steroid secretion than are concentrations in the general circulation. Increases in testicular steroid secretion as a result of minor changes in $\mathbf{L H}$ concentrations were clearly and consistently reflected in 


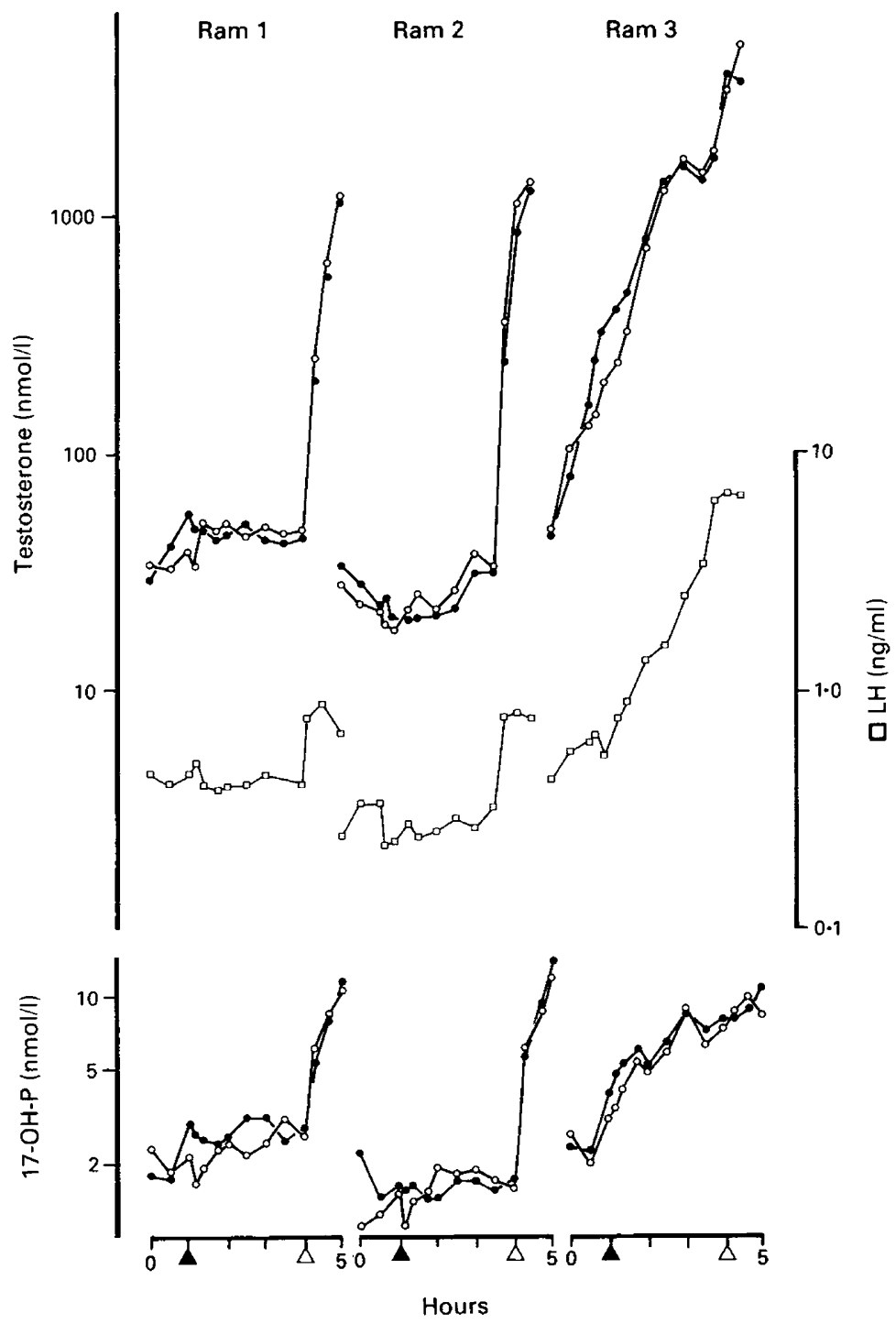

Fig. 4. Testicular venous plasma concentrations of testosterone and 17-hydroxyprogesterone (17-OHP) in saline-treated $(\mathrm{O}-\mathrm{O})$ and $\mathrm{GnRH}$-treated testes $(\mathbf{O}-\mathbf{O})$ in individual rams given $0.5 \mathrm{ng}$ GnRH over $1 \mathrm{~h}$ into one testicular artery at $1 \mathrm{~h}(\boldsymbol{\Delta})$ and $200 \mathrm{i}$.u. hCG into the cephalic vein at $4 \mathrm{~h}(\triangle)$. LH concentrations in peripheral plasma are also given $(\square)$.

increased concentrations of both testosterone and 17-hydroxyprogesterone in testicular venous blood but not in the general circulation. The marginal reflection of increased testicular steroid secretion in the general circulation can be explained by dilution. For rams in the non-breeding season, arterial blood supply averages $8.8 \pm 0.9 \mathrm{ml} / \mathrm{min}$ per testis (Noordhuizen-Stassen, 1984) which for both testes approximates $0 \cdot 4-0.5 \%$ of the heart minute volume.

Differences between venous testosterone concentrations of control and GnRH treated testes were not significant at any sampling period. This indicates that the doses of GnRH used did not directly influence testosterone secretion of the treated testis or its response to subsequent stimulation with hCG. For 17-hydroxyprogesterone a slight difference was noted between values for control and treated testes, reaching significance $(P<0.05)$ when analysed for the first hour after 
GnRH. This might indicate that GnRH slightly stimulates 17-hydroxyprogesterone secretion. The observed lack of any effect of GnRH on testosterone secretion in the ram contrasts with the reported effects of GnRH on testicular steroidogenesis in the rat (Hsueh \& Erickson, 1979; Clayton et al., 1980; Sharpe, 1982, 1984), but is in accordance with reports on other species (Wang et al., 1983; Schaison et al., 1984). Conflicting data on GnRH effects in different mammalian species may be explained by the presence or absence of GnRH receptors in gonadal tissue. So far, GnRH receptors have only been demonstrated in rat ovaries and testes but not in human (Clayton \& Huhtaniemi, 1982), primate, cow, sheep and pig (Brown \& Reeves, 1983) ovaries.

The parallel increases of testosterone and 17-hydroxyprogesterone in venous blood from both testes, after treatment of one testis only with $\mathrm{GnRH}$, suggest that the stimulated steroid secretion is the result of increased concentrations of $\mathrm{LH}$ in the general circulation. This is substantiated by the increased values of $\mathrm{LH}$ occurring within $20 \mathrm{~min}$ of $\mathrm{GnRH}$ injection in Exp. 1. The absence of such LH increases in Exp. 2 implies that $25 \mathrm{ng} \mathrm{GnRH}$ injected over $1 \mathrm{~min}$, but not $0.5 \mathrm{ng} \mathrm{GnRH}$ injected over $1 \mathrm{~h}$, can evoke $\mathrm{LH}$ release in the ram. $\mathrm{LH}$ responses in intact rams after injection of single doses of GnRH have been reported (Lincoln, 1978; Wu et al., 1987), $50 \mathrm{ng}$ producing a response of similar amplitude to those of spontaneous LH pulses. Assuming uniform mixing of the GnRH and no immediate metabolism, the concentration in the general circulation after injection of $25 \mathrm{ng}$ will approximate $6.25 \mathrm{pg} / \mathrm{ml}$ in a $50-\mathrm{kg}$ ram with an estimated blood volume of $4000 \mathrm{ml}(8 \%$ of body weight). This value is lower than concentrations $(20-60 \mathrm{pg} / \mathrm{ml})$ that occur in portal blood during spontaneous surges of GnRH in the intact ram (Caraty \& Locatelli, 1988), but apparently represents a stimulatory concentration.

The occurrence of spontaneous LH surges during the present experiment can explain the steroid and LH profiles of Ram 7 in Exp. 1 and Ram 3 in Exp. 2. From the LH profiles it is evident that injection of hCG resulted in increased values for circulating immunoreactive LH. This is most probably due to cross-reaction of hCG in the RIA used for LH. Since cross-reaction of pure hCG was $<0 \cdot 1 \%$, the less purified commercial preparation of hCG used most probably contained more cross-reacting substances.

In conclusion, the results of the present experiments show that GnRH does not stimulate testicular steroidogenesis in the ram by a direct action at the level of the testis. Small doses of GnRH $(0.5 \mathrm{ng} / \mathrm{kg})$, however, elicit release of pituitary $\mathrm{LH}$ which stimulates testicular steroidogenesis.

We thank Mr H. van Dijk, Mr O. van der Veen, Mrs G. Dijkstra and Mrs C. van Rossum-Kok for technical assistance.

\section{References}

Aten, R.F., Ireland, J.J., Weems, C.W. \& Behrman, H.R. (1987) Presence of gonadotropin-releasing hormonelike proteins in bovine and ovine ovaries. Endocrinology 120, 1727-1733.

Brown, J.L. \& Reeves, J.J. (1983) Absence of specific luteinizing hormone releasing hormone receptors in ovine, bovine, and porcine ovaries. Biol. Reprod. 29, $1179-1182$

Caraty, A. \& Locatelli, A. (1988) Effect of time after castration on secretion of LHRH and LH in the ram. J. Reprod. Fert. 82, 263-269.

Clayton, R.N. \& Huhtaniemi, I.T. (1982) Absence of gonadotropin-releasing hormone receptors in human gonadal tissue. Nature, Lond. 299, 56-59.

Clayton, R.N., Katikineni, M., Chan, V., Dufau, M.L. \& Catt, K.J. (1980) Direct inhibition of testicular function by gonadotropin-releasing hormone mediation by specific gonadotropin-releasing hormone receptors in interstitial cells. Proc. natn. Acad. Sci. USA 77, 4459-4463.

de Jong, F.H., Mallios, C., Scheck, P.A.E. \& Lamberts, S.W.J. (1984) Etomidate suppresses adrenocortical function by inhibition of $11 \beta$-hydroxylation. J. clin. Endocr. Metab. 59, 1143-1147.

Dieleman, S.J., Bevers, M.M., Poortman, J. \& Van Tol, H.T.M. (1983) Steroid and pituitary hormone concentrations in the fluid of pre-ovulatory bovine follicles relative to the peak of $\mathrm{LH}$ in the peripheral blood. J. Reprod. Fert. 69, 641-649.

Dufau, M.L., Cigorraga, S., Baukal, A.J., Sorrell, S., Bator, J.M., Neubauer, J.F. \& Catt, K.J. (1979) Androgen biosynthesis in Leydig cells after testicular desensitization by luteinizing hormone-releasing hormone and human chorionic gonadotropin. Endocrinology 105, 1314-1321.

Hsueh, A.J.W. \& Erickson, G.F. (1979) Extra-pituitary 
inhibition of testicular function by luteinizing hormone releasing hormone. Nature, Lond. 281, 66-67.

Kerr, J.B. \& Sharpe, R.W. (1986) Effects and interactions of LH and LHRH agonist on testicular morphology and function in hypophysectomized rats. $J$. Reprod. Fert. 76, 175-192.

Lincoln, G.A. (1978) Hypothalamic control of the testis in the ram. Int. J. Androl. 1, 331-441.

Noordhuizen-Stassen, E.N. (1984) Functional and morphological aspects of testicular blood supply. Thesis, University of Utrecht.

Schaison, G., Brailly, S., Vuagnat, P., Bouchard, P. \& Milgrom, E. (1984) Absence of a direct inhibitory effect of the GnRH agonist Buserelin on testicular steroidogenesis in man. J. clin. Endocr. Metab. 58, $885-888$.

Sharpe, R.M. (1982) Cellular aspects of the inhibitory actions of LHRH on the ovary and testis. J. Reprod. Fert. 64, 517-527.

Sharpe, R.M. (1984) Intratesticular factors controlling testicular function. Biol. Reprod. 30, 29-49.

Sharpe, R.M., Doogan, D.G. \& Cooper, I. (1983) Direct effects of a luteinizing hormone-releasing hormone agonist on intratesticular levels of testosterone and interstitial fluid formation in intact male rats. Endocrinology 113, 1306-1313.

Sullivan, M. \& Cooke, B. (1983) Stimulation of cholesterol side chain cleavage by a luteinizing hormonereleasing hormone (luliberin) agonist (ICI 118630) in rat Leydig cells. Biochem. J. 216, 747.

Verjans, H.L., Cooke, B.A., de Jong, F.H., de Jong, C.M.M. \& van der Molen, H.J. (1973) Evaluation of a radioimmunoassay for testosterone estimation. $J$. Steroid Biochem. 4, 665-676.

Wang, N.G., Sundaram, K., Pavlou, S., Rivier, J., Vale, W. \& Bardin, C.W. (1983) Mice are insensitive to the antitesticular effects of luteinizing hormone releasing hormone agonists. Endocrinology 112, 331-335.

Wu, F.C.W., Irby, D.C., Clarke, I.J., Cummins, J.T. \& de Kretser, D.M. (1987) Effects of gonadotropin-releasing hormone pulse-frequency modulation on luteinizing hormone, follicle-stimulating hormone and testosterone secretion in hypothalamo/pituitarydisconnected rams. Biol. Reprod. 37, 501-510.

Received 25 September 1988 